\title{
Abundance and Enzyme Activity of Airborne Microorganisms in the Experimental Green Wall System
}

\author{
Mārtiņš Kalniṇšs ${ }^{1 a}$, Laura Žorža ${ }^{1 b}$, Alise Sieriṇa ${ }^{1,2 c}$, Alvis Epners ${ }^{2 d}$ and Olga Muter ${ }^{1 e}$ \\ ${ }^{1}$ University of Latvia, Institute of Microbiology \& Biotechnology, \\ 1 Jelgavas Str., Riga LV-1004, Latvia; \\ amarcuks102@gmail.com; blau.ra@inbox.lv \\ ${ }^{2}$ LAFIVENTS Ltd, \\ 58 Bauskas Str., Riga LV-1004, Latvia; \\ calise@lafivents.lv; alvis@lafivents.lv; ${ }^{\circ}$ olga.mutere@lu.lv
}

\begin{abstract}
Recently the modern green wall (GW) systems with active air circulation, higher plants and optimized growth media are becoming increasingly more efficient for indoor air biofiltration. However, the functioning mechanisms of these complex systems are still poorly investigated. This study was focused on the activity of biofilm on the ceramic granules, which has been developed in the experimental GW within four months under realistic office conditions. Microbial abundance on the surface of ceramic granules has been evaluated by the number of culturable heterotrophic bacteria, as well as enzyme activity, i.e., fluorescein diacetate (FDA) hydrolysis and potential ammonium oxidation (PAO). Different pre-treatment types of granules, i.e., grinding and sonication, showed significant $(\mathrm{p}<0.05)$ differences in FDA and PAO activities. The microbial activity of biofilm derived from the surface of ceramic granules in pots with Epipremnum aureum placed on the $1^{\text {st }}, 3^{\text {rd }}, 5^{\text {th }}, 7^{\text {th }}$ and $9^{\text {th }}$ height levels, did not exhibit a linear dependence on the height. Particularly, the FDA hydrolysis on the granule surface varied in the range from $167.4 \mu \mathrm{g} / \mathrm{g}$ on the $3^{\text {rd }}$ level up to $463.9 \mu \mathrm{g} / \mathrm{g}$ on the $1^{\text {st }}$ level. Contribution of the $\mathrm{GW}$ to the concentration of airborne microorganisms in the air was found to be negligible. Further experiments will be focused on the GW performance in terms of biodegradation of volatile organic compounds.
\end{abstract}

Keywords: Biofilm; Ceramic granule; Green wall; Indoor air; Fluorescein diacetate hydrolysis; Potential ammonium oxidation

\section{Introduction}

The green wall (GW) systems with active air circulation, higher plants and optimized growth media combine a green interior, biofiltering, and automatic irrigation to purify indoor air from pollutants[1],[2]. However, these systems need further development to become competitive with standard indoor air filters. Optimization of filtering medium and nutrient composition, selection of plant species, as well as engineering solutions represent the great potential for improving the efficiency of GWs[3]. In this respect, the role of airborne microorganisms harbouring the GW, is not studied enough. Further characteristics of microbial diversity and activity in the GW will bring new knowledge in different aspects, i.e., increasing removal of volatile organic compounds and a potential risk factor for various health concerns [4].

The interaction of airborne microorganisms with ceramic granules in the GW results in formation of a biofilm. A remarkable increase of the metabolic rate of the immobilized microorganisms was shown. Specifically, a higher respiratory rate and metabolic activity, as well as lower lag periods have been detected [5]. However, prediction of the type and magnitude of metabolic changes of immobilized microorganisms in the biofiltration systems is rather difficult and needs a thorough study [6]. Furthermore, plant species used in the GW, are supposed to specifically influence the formation of microbial community in pots with ceramic granules. Root-associated microbes play an important role in functioning of plant-based GW, converting volatile organic compounds (VOCs) into biomass, energy, and carbon dioxide [7].

The aim of this study was to test the distribution of microorganisms among different levels of the GW, which has been installed and continuously operated for four months in the office room. 


\section{Materials \& Methods \\ 2.1. Establishing the GW}

The module was a rectangular metal box (dimensions $135 \mathrm{~cm} \times 103 \mathrm{~cm} \times 35 \mathrm{~cm}$ ) that held permeable pots containing ceramic granules and plants (Fig.1). Pots with ceramic granules and plants (3.67 L each) were stacked on nine levels (three pots per one level), besides one container with aerated water $(50 \pm 5 \mathrm{~L})$ was placed in the bottom of GW (Fig.1A). Water in the bottom container has been amended with a fertilizer (Chemopolis, Lithuania; $80 \mathrm{~mL} / 50 \mathrm{~L}$ dilution rate), with the following composition, $\mathrm{g} / \mathrm{L}$ : $\mathrm{CO}\left(\mathrm{NH}_{2}\right)_{2}-16$; $\mathrm{NH}_{2}{ }^{-}-15 ; \mathrm{NO}_{3}{ }^{-}-20 ; \mathrm{P}_{2} \mathrm{O}_{5}-44 ; \mathrm{K}_{2} \mathrm{O}-67 ; \mathrm{SO}_{3}{ }^{2-}-31 ; \mathrm{MgO}-6.1 ; \mathrm{B}^{3+}-0.06 ; \mathrm{Cu}^{2+}-0.03 ; \mathrm{Fe}^{2+}-0.17 ;$ $\mathrm{Mn}^{2+}-0.11 ; \mathrm{Zn}^{2+}-0.09$. Drip-irrigation water was dispensed from a tube running along the open top-face of the module (for $1 \mathrm{~min}$ every $20 \mathrm{~min}$ ). Simultaneous ventilation and irrigation regime were [10 $\mathrm{min}$ on/10 min off] and [1 min on/19 min off], respectively. Five plant species represented the "botanical" part of the GW, i.e., Epipremnum aureum, Anthurium andraeanum, Chlorophytum comosum, Asparagus densiflorus, Tradescantia fluminensis, with a prevalence of Epipremnum aureum. The ceramic granules (Novolukomi Keramzit, Belarus, fraction 10-16 cm) were used. Light intensity was gradually decreased from 6000 lux on the $9^{\text {th }}$ height level up to 100 lux at the $1^{\text {st }}$ height level.
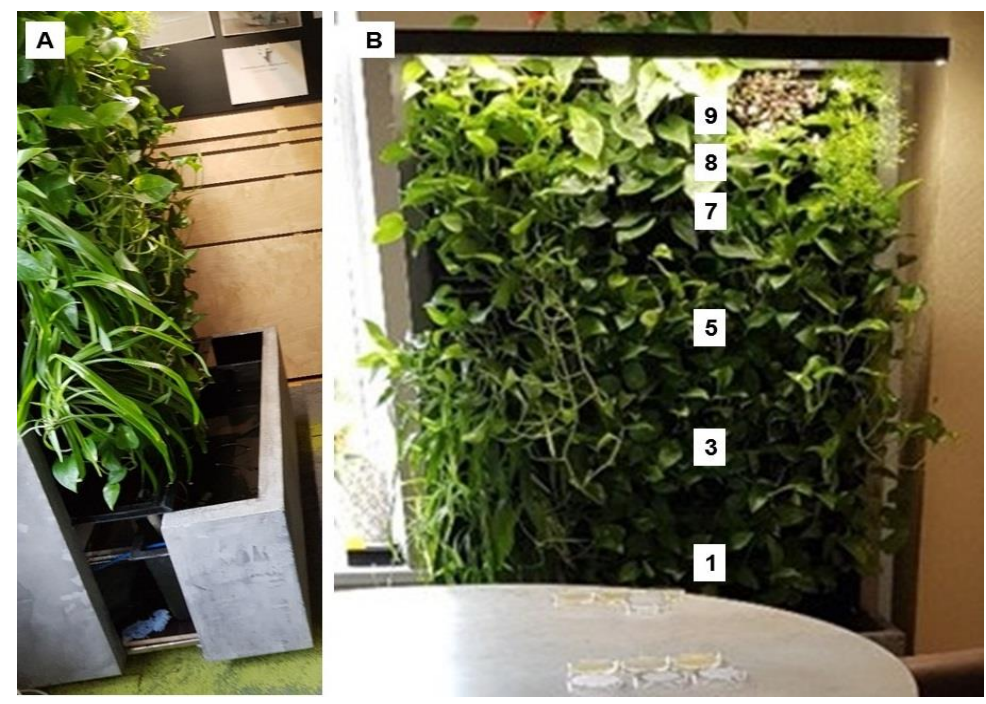

Fig. 1: The experimental green wall established in the office room. A - side view; B - frontal view with the numbered levels, where ceramic granules have been sampled.

\subsection{Sampling of ceramic granules}

After the GW was continuously operated for four months in the office room, the samples of ceramic granules were collected from the pots, which were placed on different levels (Fig.1B), particularly, near the rootzone of E. aureum ( $1^{\text {st }}, 3^{\text {rd }}, 5^{\text {th }}, 7^{\text {th }}$ and $9^{\text {th }}$ levels), A. andraeanum ( $\left.7^{\text {th }} l e v e l\right)$ and C. comosum ( $3^{\text {rd }}$ level). The samples were collected under semi-sterile conditions, i.e., sterilizing the forceps in flame after each sample. The granules were collected in the sterile sample bags and afterwards were stored at $4{ }^{\circ} \mathrm{C}$ until testing, but not longer than $72 \mathrm{~h}$.

\subsection{Preparing the ceramic granules for testing}

In sample processing, two different biofilm extraction methods were used. The first one was the grinding of ceramic granules with sterile pestle and mortar. For each sample, 3 ceramic granules were used, which were weighed, grounded and suspended in $9 \mathrm{~mL}$ of sterile deionized water. The second method was the treatment of granules in an ultrasonic bath, where the test tubes with submerged 3 granules were subjected to ultrasound for $5 \mathrm{~min}$ at $50 \mathrm{Wt}$ (Sunkko, China).

\subsection{Determination of enzyme activity and the number of colony forming units in the granule- derived biofilm}

Two enzyme groups, i.e., fluorescein diacetate (FDA) hydrolysis and potential ammonium oxidation (PAO) have been chosen for characterization of biofilm activity according to [8] and [9], respectively, with 
minor modifications. For FDA hydrolysis assay, $200 \mu \mathrm{L}$ suspension were added to $800 \mu \mathrm{L}$ FDA reaction mixture (4 mg FDA, $2 \mathrm{ml}$ acetone, $48 \mathrm{~mL} 60 \mathrm{mM}$ phosphate buffer, $\mathrm{pH}$ 7.6) in mini-reaction $2 \mathrm{~mL}$ tubes, in triplicate. The samples were incubated for $48 \mathrm{~h}$ at $30^{\circ} \mathrm{C}$. After incubation $200 \mu \mathrm{l}$ of acetone were added to samples and centrifuged at $10000 \mathrm{rpm}$ for $5 \mathrm{~min} .200 \mu \mathrm{L}$ supernatant were transferred into the microplate wells in triplicate and measured at $492 \mathrm{~nm}$ in spectrophotometer Tecan Infinite F50 (Switzerland). The amount of hydrolyzed FDA was calculated by calibration curve, which was obtained using thermally hydrolyzed FDA of known concentration.

For PAO measurement, $200 \mu \mathrm{L}$ sample were added to $800 \mu \mathrm{L}$ PAO reaction mixture $(1 \mathrm{mM}$ phosphate buffer $\left.\mathrm{pH} 7.2,200 \mathrm{mg} / \mathrm{L}\left(\mathrm{NH}_{4}\right)_{2} \mathrm{SO}_{4}, 7 \mathrm{mM} \mathrm{NaClO}\right)_{3}$ in mini-reaction $2 \mathrm{~mL}$ tubes, in triplicate. The samples were incubated for $48 \mathrm{~h}$ at $30{ }^{\circ} \mathrm{C}$. After that the samples were centrifuged at $10000 \mathrm{rpm}$ for $5 \mathrm{~min} .190 \mu \mathrm{L}$ supernatant were added to $10 \mu \mathrm{L}$ Griess reagent into wells in triplicate and measured at $492 \mathrm{~nm}$ in spectrophotometer Tecan Infinite F50 (Switzerland). The amount of oxidized ammonium to nitrites was calculated using a calibration curve obtained after the reaction of $\mathrm{NaNO}_{2}$ with Griess reagent.

The enumeration of CFU in the samples was determined by a droplet microdilution method on agar plates (Plate Count Agar, Merck, Germany). The agar plates were incubated for $48 \mathrm{~h}$ at $30{ }^{\circ} \mathrm{C}$, afterwards the CFUs were enumerated and converted to $\mathrm{CFU}$ /granule.

\subsection{Testing of microbial count in the indoor air}

The concentration of airborne microorganisms in the office room was determined by a sedimentation method. Agar plates (Plate Count Agar, Merck, Germany) were placed at different distances from the GW and exposed for $10 \mathrm{~min}$. After exposure the plates were incubated for $48 \mathrm{~h}$ at $30{ }^{\circ} \mathrm{C}$, then the CFUs were enumerated and converted to $\mathrm{CFU} / \mathrm{m}^{3}$.

\section{Results and discussion}

\subsection{Comparison of biofilm activity in dependence on granules pretreatment by grinding and sonication}

The biofilm developed on the granules surface in the pots with $E$. aureum from the $5^{\text {th }}$ height level (in the middle of the GW), was characterized after four months of GW performance by CFU count and enzyme microbial activity, i.e., FDA hydrolysis and PAO. Two methods for obtaining the biofilm for its even distribution in suspension showed considerable differences in the both CFU count and enzyme activity. Particularly, the grinded granules yielded one order higher number of CFU and $88.7 \mu \mathrm{g} / \mathrm{g}$ higher FDA hydrolysis activity than sonicated granules, whereas the PAO values were $0.071 \mu \mathrm{g} / \mathrm{g}$ higher for sonicated granules, compared to grinded ones (Fig.2). The differences between grinded and sonicated granules were found to be significant $(\mathrm{p}<0.05)$ for all three parameters tested. As was shown earlier by other authors, different types of US applications also may result in considerable differences in detaching biofilms from natural substrates [10]. The inhibition effect of grinding on the PAO activity of biofilm-derived microorganisms could be explained by ammonium fixation by clay. The clay particles fix ammonium ions as a water-insoluble and, therefore, for bacteria unavailable form [11].

A

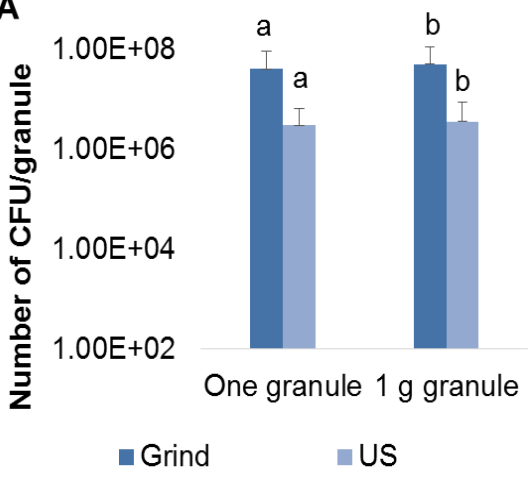

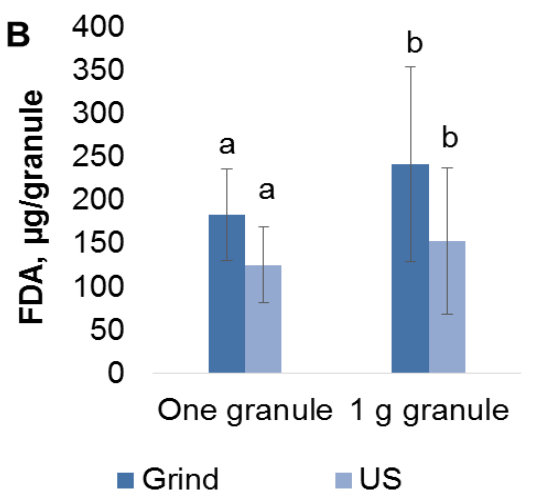

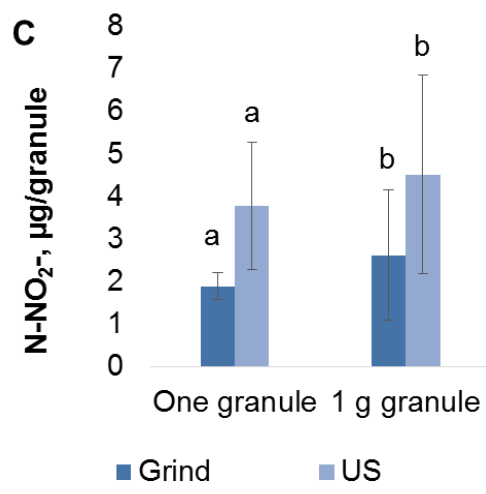

Fig. 2: Effect of granules pretreatment on the CFU count and enzyme activity in the biofilm. The biofilm was developed on the granules surface in the pots with E. aureum from the $5^{\text {th }}$ level after four months of GW performance. Grind grinded granules; US - sonicated granules. A - number of CFU; B - FDA hydrolysis activity; C - PAO activity. Statistically significant $(\mathrm{p} \leq 0.05)$ data are indicated with the same letter. 


\subsection{Characteristics of microbial activity on the granules sampled on the different height levels of the GW}

The microbial activity of biofilm derived from the surface of ceramic granules was compared in seven pots differed by the height level and plant species. No linear dependence of FDA hydrolysis and PAO activity on the height level was shown (Fig.3). FDA hydrolysis on the granule surface in pots with $E$. aureum varied in the range from $167.4 \mu \mathrm{g} / \mathrm{g}$ on the $3^{\text {rd }}$ level up to $463.9 \mu \mathrm{g} / \mathrm{g}$ on the $1^{\text {st }}$ level. These data are attributed to the grinded granules, while the testing of sonicated granules showed a decreased FDA hydrolysis activity, compared with grinded ones. These data are in a good agreement with those summarized in Fig.2B. The PAO activity did not vary considerably among the different height levels in pots with $E$. aureum. Comparison of pots with different plant species showed the differences in activity of both enzyme groups tested. The lowest PAO activity was detected in pots with A. andraeanum, compared with E. aureum and C. comosum (Fig.3B).

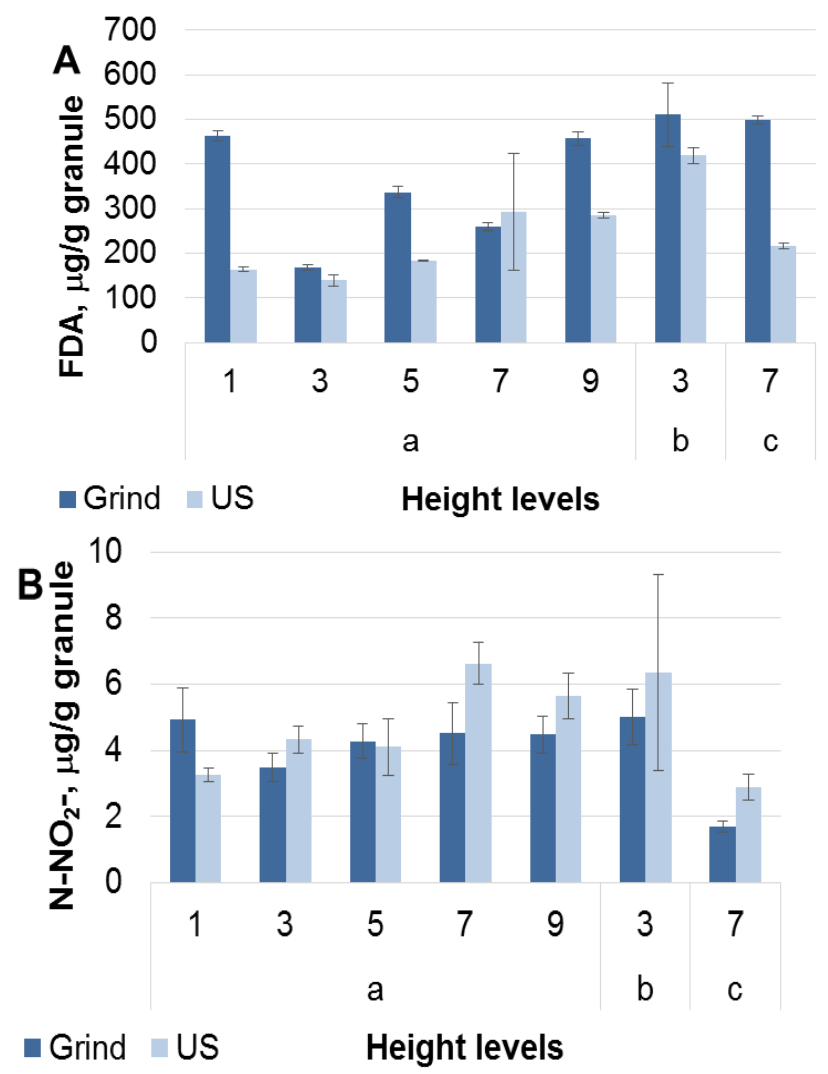

Fig. 3: The microbial activity of biofilm derived from the surface of ceramic granules being incubated with higher plants on different height levels of the GW for five months. A - FDA hydrolysis; B - PAO activity. a- E. aureum; b - C. comosum; c - A. andraeanum. Grind - grinded granules; US - sonicated granules.

\subsection{Effect of GW on the abundance of microorganisms in the indoor air}

One of the tasks of this study was to evaluate a contribution of the GW to the density of airborne microorganisms in the office room. The air samples have been collected three times during the day, i.e., in the morning without central conditioning, $5 \mathrm{~min}$ after conditioning has been turned on, and in the afternoon after the working day. The Fig.4 summarizes the changes in the concentration of microorganisms in air at different distances on the GW. Comparison of the concentration of airborne microorganisms in the nonconditioned office air in the morning at $0.5 \mathrm{~m}$ and $5.0 \mathrm{~m}$ distance from the $\mathrm{GW}$ showed increased CFU values near the $\mathrm{GW}$, i.e., $705 \mathrm{CFU} / \mathrm{m}^{3}$ and $176 \mathrm{CFU} / \mathrm{m}^{3}$, respectively. However, the central air conditioning resulted in a decrease of the CFU counts at all tested points up to $59 \div 294 \mathrm{CFU} / \mathrm{m}^{3}$, irrespectively of the distance from the GW. The most considerable increase of the concentration of airborne microorganisms in the office room was detected after the working day, due to the human occupancy. The CFU number in the 
air varied in the range from $881 \mathrm{CFU} / \mathrm{m}^{3}$ to $1881 \mathrm{CFU} / \mathrm{m}^{3}$. No linear dependence on the distance from the GW was found (Fig.4).

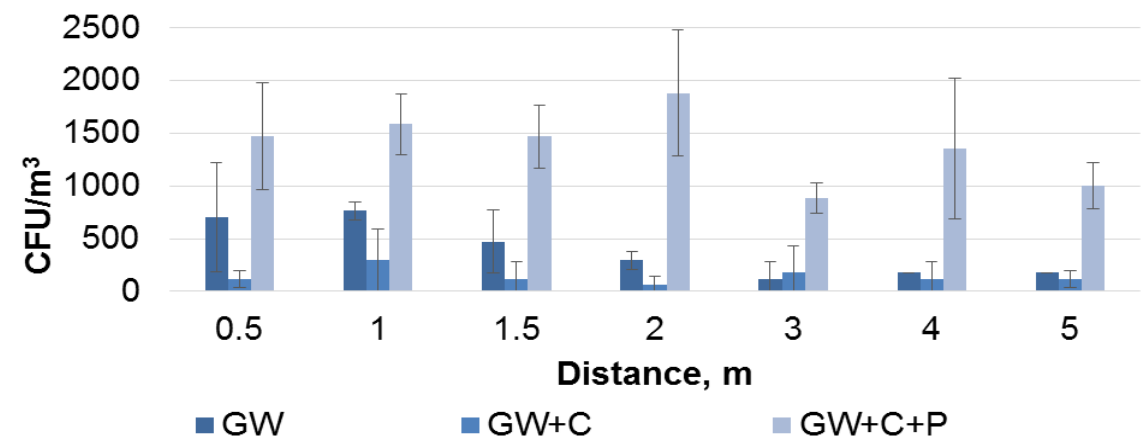

Fig. 4: Indoor air microbiological contamination in dependence on the distance from $\mathrm{GW}$ and sampling period. $\mathrm{GW}$ - green wall; $\mathrm{C}$ - air conditioning; $\mathrm{P}$ - office personnel.

These data are in a good agreement with the results of other authors. Thus, Hospodsky et al. [12] [13] reported that a human occupancy leads to significant increases of total particle mass and bacterial genome concentrations. A human-occupied environment is characterized by an abundance of bacteria specific to the skin, nostrils, and hair of humans in indoor air and in floor dust [14]. Nevertheless, it was recently concluded that active biofilters are unlikely to make hazardous contribution to indoor microorganisms [15].

\section{Conclusions}

1.Two alternative methods for detaching the biofilm from ceramic granules, i.e., grinding and sonication, resulted in a significantly $(\mathrm{p}<0.05)$ higher yield of CFU and FDA hydrolysis activity in grinded samples, compared to sonicated ones. However, the PAO activity was higher in sonicated samples, probably due to fixation of ammonium ions by clay particles.

2.The microbial activity of biofilm derived from the surface of ceramic granules in pots with E. aureum placed on the $1^{\text {st }}, 3^{\text {rd }}, 5^{\text {th }}, 7^{\text {th }}$ and $9^{\text {th }}$ height levels, did not exhibit a linear dependence on the height. Particularly, the FDA hydrolysis on the granule surface varied in the range from $167.4 \mu \mathrm{g} / \mathrm{g}$ on the $3^{\text {rd }}$ level up to $463.9 \mu \mathrm{g} / \mathrm{g}$ on the $1^{\text {st }}$ level.

3.Comparison of the concentration of airborne microorganisms in air near the $\mathrm{GW}$ at different periods of the working day showed some negligible increase of CFU near the GW in the morning in a nonconditioned office room, i.e., $705 \mathrm{CFU} / \mathrm{m}^{3}$ and $176 \mathrm{CFU} / \mathrm{m}^{3}$, at $0.5 \mathrm{~m}$ and $5.0 \mathrm{~m}$ distance from the $\mathrm{GW}$, respectively. The most considerable impact on air contamination by microorganisms was detected after the working day, because of human occupancy, when the CFU number in the air varied in the range from 881 $\mathrm{CFU} / \mathrm{m}^{3}$ to $1881 \mathrm{CFU} / \mathrm{m}^{3}$ irrespective of a distance from the $\mathrm{GW}$.

\section{Acknowledgements}

The study was conducted in collaboration with Lafivents" Ltd. within the framework of the project "Research and development of bioremediation-based indoor air biofiltration system" in accordance with the contract No.1.2.1.1./18/A/001 between „ETKC“ Ltd. and the Central Finance and Contracting Agency with support from the European Regional Development Fund (ERDF).

\section{References}

[1] A. Mikkonen, T. Li, M. Vesala, J. Saarenheimo, V. Ahonen, S. Kärenlampi, J.D. Blande, M. Tiirola, A. Tervahauta, "Biofiltration of airborne VOCs with green wall systems-Microbial and chemical dynamics", Indoor Air. (2018). https://doi.org/10.1111/ina.12473.

[2] F. Torpy, P. Irga, N. Clements, C. He, M. Pollinger, I. Mulvihill, A. Dengel, "Testing the single-pass VOC removal efficiency of an active green wall using methyl ethyl ketone (MEK)", Air Qual. Atmos. Heal. (2018). https://doi.org/10.1007/s11869-017-0518-4.

[3] T. Pettit, P.J. Irga, P. Abdo, F.R. Torpy, "Do the plants in functional green walls contribute to their 
ability to filter particulate matter?", Build. Environ. (2017). https://doi.org/10.1016/j.buildenv.2017.09.004.

[4] Y. Zhai, X. Li, T. Wang, B. Wang, C. Li, G. Zeng, "A review on airborne microorganisms in particulate matters: Composition, characteristics and influence factors", Environ. Int. (2018). https://doi.org/10.1016/j.envint.2018.01.007.

[5] M.A. Heitkamp, V. Camel, T.J. Reuter, W.J. Adams, "Biodegradation of p-nitrophenol in an aqueous waste stream by immobilized bacteria", Appl. Environ. Microbiol. (1990).

[6] M.S. Sheldon, H.J. Small, "Immobilisation and biofilm development of Phanerochaete chrysosporium on polysulphone and ceramic membranes", J. Memb. Sci. (2005). https://doi.org/10.1016/j.memsci.2005.04.014.

[7] J.A. Russell, Y. Hu, L. Chau, M. Pauliushchyk, I. Anastopoulos, S. Anandan, M.S. Waring, "Indoorbiofilter growth and exposure to airborne chemicals drive similar changes in plant root bacterial communities", Appl. Environ. Microbiol. (2014). https://doi.org/10.1128/AEM.00595-14.

[8] W. Chen, "The Role of Microbial Activity in Suppression of Damping-Off Caused by Pythium ultimum", Phytopathology. (1988). https://doi.org/10.1094/phyto-78-314.

[9] L.W. Belser, E.L. Mays, "Specific inhibition of nitrite oxidation by chlorate and its use in assessing nitrification in soils and sediments", Appl. Environ. Microbiol. (1980).

[10] F. Mermillod-Blondin, G. Fauvet, A. Chalamet, M.C. Des Châtelliers, "A comparison of two ultrasonic methods for detaching biofilms from natural substrata", Int. Rev. Hydrobiol. (2001). https://doi.org/10.1002/1522-2632(200106)86:3<349::AID-IROH349>3.0.CO;2-B.

[11] R. Nieder, D.K. Benbi, H.W. Scherer, "Fixation and defixation of ammonium in soils: A review", Biol. Fertil. Soils. (2011). https://doi.org/10.1007/s00374-010-0506-4.

[12] D. Hospodsky, J. Qian, W.W. Nazaroff, N. Yamamoto, K. Bibby, H. Rismani-Yazdi, J. Peccia, "Human occupancy as a source of indoor airborne bacteria", PLoS One. (2012). https://doi.org/10.1371/journal.pone.0034867.

[13] J. Qian, D. Hospodsky, N. Yamamoto, W.W. Nazaroff, J. Peccia, "Size-resolved emission rates of airborne bacteria and fungi in an occupied classroom", Indoor Air. (2012). https://doi.org/10.1111/j.1600-0668.2012.00769.x.

[14] D. Hospodsky, N. Yamamoto, W.W. Nazaroff, D. Miller, S. Gorthala, J. Peccia, "Characterizing airborne fungal and bacterial concentrations and emission rates in six occupied children's classrooms", Indoor Air. (2015). https://doi.org/10.1111/ina.12172.

[15] P.J. Irga, P. Abdo, M. Zavattaro, F.R. Torpy, "An assessment of the potential fungal bioaerosol production from an active living wall", Build. Environ. (2017). https://doi.org/10.1016/j.buildenv.2016.11.004. 